\title{
A study of Curtailment Behaviour in the Context of University Students in Indonesia: The Role of Values and Norms
}

\author{
Nosica RIZKALLA ${ }^{1}$ \\ PURNAMANINGSIH ${ }^{2}$ \\ Trihadi Pudiawan ERHAN ${ }^{3}$
}

\begin{abstract}
Consumer nowadays have become more aware of environmental issues which urge them to act more sustainably. One of the ways to behave more sustainably is conserving the energy. Consumers can conserve the energy by engaging in curtailment behaviour. Curtailment behaviour is believed to be more reliable and realistic in combating environmental problems, However, curtailment behaviours are still relatively difficult to be fully adopted by the individuals because they usually require sacrifice from the individuals. Therefore, it is fundamental to explore what factors can encourage consumers to engage in curtailment behaviour. This study attempts to explain curtailment behaviour from socio-psychological factors, represented by values and norms. A research model consisting of altruistic values, egoistic values, biospheric values, personal norms, social norms as predictors was then proposed and tested using multiple regression. The total number of 263 respondents were involved in this study. This study found that altruistic values play the biggest contribution in explaining curtailment behaviour of university students in Indonesia, followed by biospheric values and personal norms. Meanwhile, egoistic values and social norms were proven to be insignificant. The result of this study provides understanding for government as a policy maker, as well as university as the education provider in composing the right approach to encourage the adoption of curtailment behaviour in the context of university students in Indonesia. Additionally, limitation and suggestion for further studies were also presented in later part of this paper.
\end{abstract}

KEYWORDS: altruistic values, biospheric values, curtailment behaviour, egoistic values, personal norms, social norms

\section{JEL CLASSIFICATION: $C 12, M 31$}

\section{INTRODUCTION}

Consumers nowadays have already been aware of the seriousness of environmental issues and how their behaviour can contribute to environmental preservation. Indeed, the role of consumers is highly needed in overcoming environmental problems. Consumer can make a difference in environmental condition through their choice in consumption and their behaviour (Bronfman et al., 2015). Consumer can conduct pro-environmental behaviours in several ways, for example recycling the product (Onel \& Mukherjee, 2017), purchasing environmentally-friendly behaviour (Ibtissem, 2010), and conserving the energy (Dermody et al., 2018).

\footnotetext{
${ }^{1}$ Universitas Multimedia Nusantara, Indonesia, nosica.rizkalla@umn.ac.id

${ }^{2}$ Universitas Multimedia Nusantara, Indonesia

${ }^{3}$ Universitas Multimedia Nusantara, Indonesia
} 
Energy conservation has been believed as one of effective solutions to overcome environmental problems (Yeboah \& Kaplowitz, 2016). Society depends a lot on the use of energy in order to fulfill their daily needs, like to get water, to operate electrical appliances etc. This also occurs in Indonesia, in which Indonesia was included in the list of countries with most energy consumption in 2017 (Ferial, 2017). This dependency urges the consumers to conserve the energy as the source of this energy is unrenewable (Nordlund \& Garvill, 2003). In Indonesia, this conservation energy agenda has been the one of the top priorities of Ministry of Energy and Mineral Resources of the Republic of Indonesia.

One of the ways to initiate energy conversion is through curtailment behaviour. Curtailment behaviours are behaviours that conducted on everyday basis, usually incurring less or no cost, and requiring efforts for the individual who do it (Jansson et al., 2010). It can be in the form of recycling behaviour, vehicle use reduction and water and energy conservation (Jansson et al., 2010). According to (Jansson et al., 2010), nowadays curtailment behaviours have been more highlighted compared to purchasing behaviour. Curtailment behaviours are considered more realistic in combating environmental problems than purchasing behaviour due to the fact that there is still lack of availability of environmentally-friendly products in the market. In Indonesia itself, starting from 2016, Ministry of Energy and Mineral Resources of the Republic of has encouraged the society to be involved in "10\% cut movement" (Marroli, 2017). This movement involves the whole element of society, from government, business to individuals. Under this movement, the society is encouraged to reduce $10 \%$ of their energy consumption. This movement is believed to be able to contribute to energy preservation. However, curtailment behaviours are still relatively difficult to be fully adopted by the individuals because they usually require sacrifice from the individuals (Gardner \& Abraham, 2007). The sacrifice includes doing extra effort and changing life habit.

In order to be able to stimulate and influence curtailment behaviour from the consumers, an understanding of what factors can encourage this behaviour is needed (Nordlund \& Garvill, 2003). However, as mentioned by (Urien \& Kilbourne, 2011), due to the complexity of proenvironment behaviours, not all factors can be included in the environmental behaviours all at once. Therefore, it is suggested to investigating these behaviours from one perspective at one time. One of the factors believed to be able to affect consumers' sustainable consumption behaviour is socio-psychological factors (Tanner \& Kast, 2003). In addition, many studies even believe that the change in behaviour can only be personified if there is a change in individuals' socio-psychological state (Robinson \& Smith, 2002). According to (Nordlund \& Garvill, 2003), socio-psychological factors like norms, beliefs and values has been proven to be able to cause change in individual's behaviour, including those related to environment issues, like recycling, purchasing and conservation behaviour.

This study would explore curtailment behaviour from psychological perspective on university students in Indonesia. There has been an increasing interest in evaluating how university students would react to the issue of sustainability and environment (Muller-Christ et al., 2014). University is considered as an effective place to encourage the application of sustainable consumption behaviour. University students are in the age where their values, beliefs and norms go through the transitional phase (Whitley et al., 2016) and have not been solidified yet (Sheldon, 2005). It is believed that the values, norms and beliefs formed during this period would be internalized for a long time and shape the behaviour of the students in the future (Cortese, 2003). 


\section{LITERATURE REVIEW}

\subsection{Sustainable Consumption Behaviour}

Sustainable consumption is proposed to be the alternative of traditional consumption pattern which are deemed to have a significant contribution in today's environmental problems (Wang, 2017). Sustainable consumption is also predicted to be effective in reducing the damage in environment as this consumption does not only focus on the needs of current generation, but also focus on the economic, social, and environmental needs of future generations (Luchs et al., 2011). By definition, sustainable consumption behaviour is the type of consumption which focuses on economic, social and environmental needs of both current and future generations (Luchs et al., 2011). According to Ibtissem (2010), individuals can perform sustainable consumption behaviours in several ways, from recycling their waste, buying environmentally-friendly product, to conserving the energy. This study would focus on energy conservation or curtailment behavior.

\subsection{Values}

Values are defined as the principles or standards that as a guidance in an individual's life (Schwartz, 1992). One of the most used model of human values in the context of environmental issues is the modal from Schwartz (Schultz et al., 2005). Schwartz (1992) formulated 10 values type which further classified into 4 categories, namely conservatism, openness to change, self-transcendence and self enhancement (Schwartz, 1992). It is mentioned that among these 4 values categories, self-transcendence and self enhancement are better in explaining environmental-related behaviour compared to the rest (Nordlund \& Garvill, 2003).

Self-transcendence values, or also known as altruistic values, are focusing on other human goals and benefits (De Groot et al., 2012). People with high altruistic values feel that they have to protect the environment because the damage in environment can affect other people (Schultz \& Zelegny, 1999). Meanwhile, self-enhancement or egoistic values are focusing on self-benefits or interests (De Groot et al., 2012). People with high egoistic values feel that they are obliged to protect the environment because the damage in environment can endanger their own state (Schultz \& Zelezny, 1999). For them, the reason why the environment need to be preserved is because they do not want to drink polluted water, they do not want to breathe polluted water etc (Schultz \&Zelezny, 1999).

In the relation of environmental context, it is argued that the intrinsic value of nature should also be acknowledged (De Groot \& Steg, 2008). Furthermore, Stern (2000) proposed that besides altruistic and egoistic values, biospheric values may also be relevant to explain environmental behaviour. At first, several scholars postulated that biospheric values are a part of self-transcendence values, along with altruistic values (Stern et al., 1993). However, Stern et al (1998) stated that it is important to differentiate altruistic and biospheric values as both values represent a different spectrum of motivations to act more sustainably. While altruistic values relate with the welfare of others and egoistic values relate to welfare of one self, biospheric values focus on the welfare of environment itself (De Groot \& Steg, 2008), without a clear link to the welfare of human beings (Bouman et al., 2018). People with high biospheric values will base their choice and decision on the benefits of ecosystems and biosphere. In the past studies, values have been linked with environmental attitudes and behaviour (Schultz et al., 2005). Here, altruistic values are believed to be able to affect a wide spectrum of construct like attitude, intention and behaviour (Urien \& Kilbourne, 2010). It is also concluded that people who base their decision on altruistic and biospheric value would be more inclined to 
conduct pro environmental behaviour, while those who base their decisions on egoistic value would be less inclined to do so (Bouman et al., 2018). Based on these notions, the following hypotheses are proposed.

$\mathrm{H}_{1}$ : Altruistic Values have a positive effect on curtailment behaviour

$\mathrm{H}_{2}$ : Egoistic Values have a negative effect on curtailment behaviour

$\mathrm{H}_{3}$ : Biospheric Values have a positive effect on curtailment behaviour

\subsection{Personal Norms}

According to Schwartz, personal norms are self-expectations that are formed by internalized values (Harland et al., 1999). Specifically, they are "self-expectation of specific action in a particular situation, experienced as a feeling of moral obligation". (Onel \& Mukherjee, 2017; Schwartz, 1977 in Jansson \& Dorrepaal, 2015) postulated that the expectation of how an individual should behave is based on his/her own internal values. When individuals act in accordance to their internalized norms, this may lead to sense of pride or self-appreciation (Harland et al., 2007). It is mentioned that when personal norms are activated, they would able to influence behaviour (Harland et al., 1999). In the regards of environment, personal norms can be identified as moral obligations to act more responsibly towards the environment (Liu et al., 2018). It is believed that personal norms can influence both prosocial intention and actual behaviour (Manstead, 2000). It is also proven that personal norms are able various types of behaviour, like purchasing behaviour (Tanner \& Kast, 2003), recycling behaviour (Thorgersen, 2006) and curtailment behaviour (Nordlund \& Garvill, 2003). Based on these notions, a following hypothesis is proposed

\section{$\mathrm{H}_{4}$ : Personal norms has a positive effect on curtailment behaviour}

\subsection{Social Norms}

Values-beliefs-norms theory has been proven to be able to influence wide range of proenvironmental behaviour, from recycling to purchasing behaviour (Dietz et al., 2015). However, it is mentioned that the beliefs which are represented by NEP in this model cannot be applied on all types of culture (Klain et al., 2017). As NEP scales were constructed based on western individual context, they are not always applicable to other culture, especially those with collectivistic nature (Medina et al., 2019). As suggested by (Medina et al., 2019), for collectivistic culture, a factor which emphasizes on social relationship should also be considered in understanding pro-environmental behaviour. And this factor can be represented by social norms. Social norms can be considered as shared rule of what being approved and disapproved by an individual's surrounding (Elster, 1989). Similarly, it is defined as a belief whether a certain behaviour would be approved by an individual's social surrounding (Onel \& Mukherjee, 2017). Social norms between one individual to another would be different as these are learned through the interactions and socializations process from the group in which an individual belongs to (Jansson et al., 2017). Social norms have been proven to be able to influence various type of pro-environmental behaviour, like recycling (Andersson \& von Borgstede, 2010), purchasing eco-friendly products (Kim et al., 2012) and conservation behaviour (Ando et al., 2017). Thus, we propose the following hypothesis:

$\mathrm{H}_{5}$ : Social norms have a positive effect on conservation behaviour

\subsection{Research Framework}

Based on the conducted literature review and proposed hypotheses, this study will try to investigate sustainable consumption behaviour, specifically curtailment behaviour from the 
socio-psychological perspective, represented by values and norms. The framework of this study consists of 5 independent variables, namely altruistic values, egoistic values, biospheric values, personal norms and social norms, and 1 dependent variable, namely curtailment behaviour. Thus, this research model is proposed:

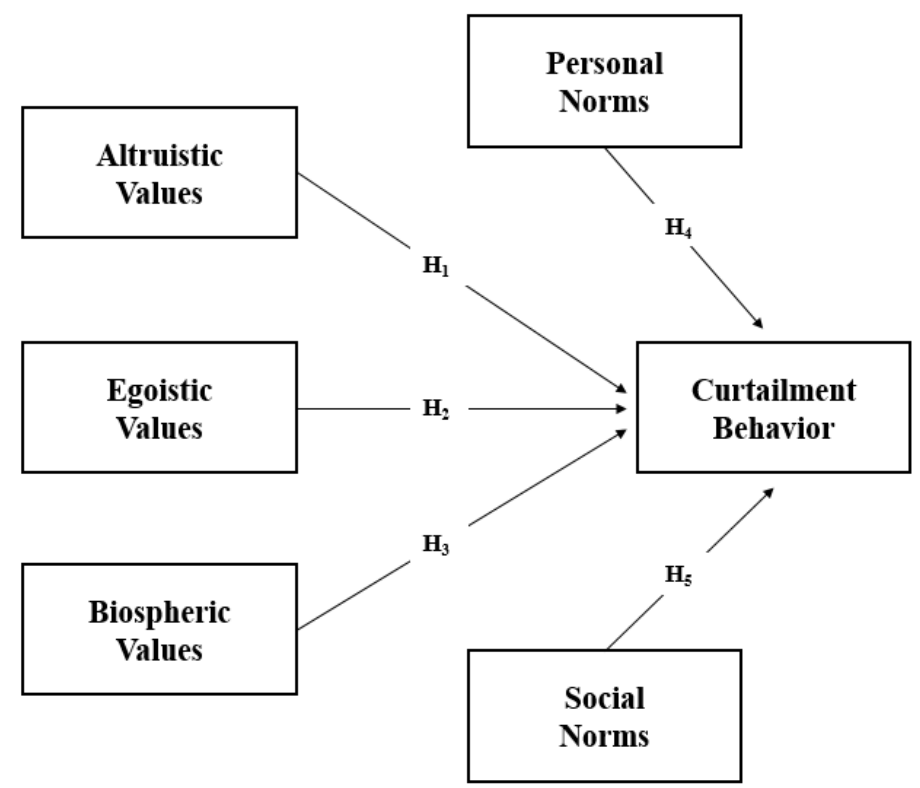

Figure 1. Research Framework

Source: Author

\section{METHODOLOGY}

\subsection{Sample and Methodology}

The population in this study is students of Universitas Multimedia Nusantara, one of private universities in Indonesia. Currently, this university consists of 4 faculties with 13 study programmes. As a university, Universitas Multimedia Nusantara also takes the sustainability and environmental issue seriously. This is proven by the design of the buildings which are deemed to be energy-saving and environmentally-friendly. The buildings of Universitas Multimedia Nusantara even won the 3rd place of Subroto Award which is an award for most energy-saving building. For research design, this study implemented conclusive research design, specifically descriptive research design as the objective of this research is to describe and test the relationships between proposed independent variables (altruistic values, egoistic values. biospheric values, personal norms and social norms) and dependent variable (curtailment behaviour). The number of respondents used in this study are 263 students from 4 faculties in Universitas Multimedia Nusantara. The response from the respondents will be collected one time (single cross-sectional design) by using a questionnaire consisting multiitem scales related to research variables. After the data had been collected, this study would test the validity and reliability of the scales by conducting by using factor analysis and cronbach's alpha. This study then employed t-test and multiple regression analysis to test research hypotheses. The analysis was conducted by using SPSS version 23.

\subsection{Measurement}

In this study, all latent variables in were assessed by using multiple statements on five-point likert scale ranging from (1) "very unimportant" to (5) "very important" for altruistic, egoistic and biospheric values and from (1) "very disagree" to (5) "very agree" for personal norm, social norm and curtailment behaviour. All the measurements were adapted from previous 
studies with slight modifications for several scales in order to tailor them to this study's specific context. In this study, the scales to measure altruistic, egoistic and biospheric value environmental concern were adapted from (De Groot \& Steg, 2008). Meanwhile, personal norms were measured by scales adopted from (Steg et al., 2005). As for social norms, this study adapted the scales from (Golob et al., 2018). For curtailment behaviour, this study used the measurement from (Dermody et al., 2018).

\section{RESULT}

\subsection{Sample Characteristics}

As presented on table 1, the sample of this study comprise of $63 \%$ female and $37 \%$ male. Most of them are 19 years old (39\%) and 18 years old (29\%). In regards of study program, the proportion is pretty equally distributed, with $32 \%$ them are from faculty of communication, $27 \%$ are from faculty of business, $24 \%$ are from faculty of art and design and $15 \%$ are from faculty of information and technology. As from grade, most of them are in their 2nd year, scoring for $44 \%$. This study also tried to assess whether the respondents had received formal education or seminar about energy conservation before, and as can be seen on Table 1, 56\% of them stated that they have attended at least 1 seminar about energy conservation, while the rest $44 \%$ have not attended at all.

Table 1. Summary of Sample Characteristic

\begin{tabular}{|c|c|c|c|}
\hline & \multirow{2}{*}{ Percentage } & \multicolumn{2}{|c|}{ Curtailment Behaviour } \\
\hline & & Avg.Score & Sig \\
\hline \multicolumn{4}{|l|}{ Gender } \\
\hline Female & $63 \%$ & 4.22 & \multirow[t]{2}{*}{0.012} \\
\hline Male & $37 \%$ & 4.05 & \\
\hline \multicolumn{4}{|l|}{ Age } \\
\hline 18 & $29 \%$ & 4.07 & \multirow[t]{5}{*}{0.301} \\
\hline 19 & $39 \%$ & 4.17 & \\
\hline 20 & $14 \%$ & 4.29 & \\
\hline 21 & $12 \%$ & 4.11 & \\
\hline 22 & $3 \%$ & 4.22 & \\
\hline \multicolumn{4}{|l|}{ Program } \\
\hline Faculty of Business & $27 \%$ & 4.15 & \multirow[t]{4}{*}{0.000} \\
\hline Faculty of Communication & $32 \%$ & 3.90 & \\
\hline Faculty of Art and Design & $24 \%$ & 4.30 & \\
\hline Faculty of Information and Technology & $15 \%$ & 4.47 & \\
\hline \multicolumn{4}{|l|}{ Grade } \\
\hline $1^{\text {st }}$ Year & $34 \%$ & 3.68 & \multirow[t]{4}{*}{0.000} \\
\hline $2^{\text {nd }}$ Year & $44 \%$ & 4.19 & \\
\hline $3^{\text {rd }}$ Year & $14 \%$ & 4.79 & \\
\hline $4^{\text {th }}$ Year & $7 \%$ & 4.91 & \\
\hline \multicolumn{4}{|l|}{ Formal Seminar about Energy Conservation } \\
\hline Yes & $56 \%$ & 4.46 & \multirow[t]{2}{*}{0.00} \\
\hline No & $44 \%$ & 3.76 & \\
\hline
\end{tabular}

This study also attempts to investigate whether there is a significant difference of curtailment behaviour in each demographic groups by conducting a t-test. Based on gender, it can be concluded that there is a significant difference in curtailment score in which female 
respondents score higher with average score of 4.22, while male respondent score lower with average score of 4.05 . There is also a significant difference in curtailment behaviour based on study program in which those from faculty of information and technology score the highest with average score of 4.47. A significant difference is also found on degree category, where students in their 4th year score the higher in curtailment behaviour with average score of 4.91 . This study also found that information and education plays a significant role in curtailment behaviour of the students, proven by the average score of those who had received formal education and seminar about energy conservation is higher compared to those who had not received any formal education or seminar. The score is 4.46 against 3.76.

\subsection{Validity and Reliability Analysis}

Since this study used multi-item scales to assess each variable employed in the model, the applicability and accuracy of the scaless need to be evaluated (Malhotra, 2010). This can be done by validity and reliability analysis (Knapp and Mueller, 2010).

Table 2. Validity and Reliability Analysis Result

\begin{tabular}{|c|c|c|c|c|}
\hline Variable & Item & Factor Loading & KMO & Cronbach's Alpha \\
\hline \multirow{5}{*}{ Egoistic Values } & EGV1 & 0.597 & \multirow{5}{*}{0.689} & \multirow{5}{*}{0.604} \\
\hline & EGV2 & 0.648 & & \\
\hline & EGV3 & 0.730 & & \\
\hline & EGV4 & 0.611 & & \\
\hline & EGV5 & 0.522 & & \\
\hline \multirow{4}{*}{ Altruistic Values } & ALV1 & 0.588 & \multirow{4}{*}{0.677} & \multirow{4}{*}{0.602} \\
\hline & ALV2 & 0.735 & & \\
\hline & ALV3 & 0.703 & & \\
\hline & ALV4 & 0.677 & & \\
\hline \multirow{4}{*}{ Biospheric Values } & BIOV1 & 0.827 & \multirow{4}{*}{0.726} & \multirow{4}{*}{0.784} \\
\hline & BIOV2 & 0.819 & & \\
\hline & BIOV3 & 0.700 & & \\
\hline & BIOV4 & 0.776 & & \\
\hline \multirow{5}{*}{ Personal Norms } & PN1 & 0.690 & \multirow{5}{*}{0.792} & \multirow{5}{*}{0.805} \\
\hline & PN2 & 0.812 & & \\
\hline & PN3 & 0.715 & & \\
\hline & PN4 & 0.834 & & \\
\hline & PN5 & 0.711 & & \\
\hline \multirow{5}{*}{ Subjective Norms } & SN1 & 0.712 & \multirow{5}{*}{0.639} & \multirow{5}{*}{0.647} \\
\hline & SN2 & 0.690 & & \\
\hline & SN3 & 0.616 & & \\
\hline & SN4 & 0.618 & & \\
\hline & SN5 & 0.586 & & \\
\hline \multirow{3}{*}{ Curtailment Behaviour } & SCB1 & 0.781 & \multirow{3}{*}{0.632} & \multirow{3}{*}{0.603} \\
\hline & SCB2 & 0.772 & & \\
\hline & SCB3 & 0.698 & & \\
\hline
\end{tabular}

The validity of the scales in this study is assessed by conducting factor analysis. The scales would be considered valid if the factor loading of each indicators exceeds the cut off value of 0.5 (Stevens, 2009). Meanwhile, the reliability of the scales would be evaluated by calculating Cronbach's Alpha score. The scales would be deemed reliable if the alpha score is bigger than 0.6 (Malhotra, 2010). As can be seen on table 2, all scales are proven to be valid and reliable as the factor loading and cronbach's alpha score are greater than the determined cut off value. Thus, the scales can be used for further analysis. 


\subsection{Hypotheses Testing}

Multiple regression analysis was conducted to test hypotheses used in this study. The summary of regression analysis is presented on Table 3. The results show that the model is significant with F-Value of 12.760, significance level of 0.00 and Adjusted $\mathrm{R}^{2}$ of 0.183 which can be interpreted that $18.3 \%$ variance of curtailment behaviour can be accounted for by its significant predictors, which are altruistic values, egoistic values, biospheric values, personal norms and social norms. According to the result, altruistic values $(\beta=0.362, p=0.000)$, biospheric values $(B=0.189, \mathrm{p}=0.017)$, personal norms $(\beta=0.172, \mathrm{p}=0.010)$ have a significant effect on curtailment behaviour. On the contrary, egoistic values $(\beta=-0.052, p=$ $0.573)$ and social norms $(\beta=0.017, \mathrm{p}=0.795)$ have no significant effect on curtailment behaviour.

Table 3. Summary of Multiple Regression Analysis

\begin{tabular}{|l|c|c|c|c|c|}
\hline & Beta & t-values & Sig & F Values & Ad R $^{2}$ \\
\hline Constant & 1.167 & 2.256 & $0.025^{*}$ & \multirow{2}{*}{12.760} & \multirow{2}{*}{$18.3 \%$} \\
\hline Egoistic Values & -0.052 & -0.565 & 0.573 & & \\
Altruistic Values & 0.362 & 4.162 & $0.000^{*}$ & & \\
\cline { 1 - 4 } Biospheric Values & 0.189 & 2.399 & $0.017^{*}$ & & \\
\cline { 1 - 4 } Personal Norms & 0.172 & 2.596 & $0.010^{*}$ & & \\
\hline Social Norms & 0.017 & 0.260 & 0.795 & & \\
\hline
\end{tabular}

Note: * denotes significance at the $5 \%$ level

Source: Author

\subsection{Discussion}

This study attempt to explain curtailment behaviour of university students in Indonesia from socio-psychological perspectives which are represented by altruistic values, egoistic values, biospheric values, personal norms and social norms. After conducting the hypothesis testing, it can be concluded that 3 out of 5 predictors are proven to be able to affect curtailment behaviour. The aforementioned variables are altruistic values, biospheric values and personal norms.

In this model, altruistic values are found to be the strongest predictor of curtailment behaviour, proven by the beta value of 0.189 , which is bigger compared others' beta value. As asserted by (Dermody et al., 2018), curtailment behaviour can be better explained by altruistic values, while egoistic values are found to be failed to do so. This also occurs in this study where egoistic values are proven to be insignificant in explaining curtailment behaviour. The possible reason behind this may be because individuals who endorse egoistic values regard curtailment behaviour as something unpleasant and inconvenient (Liobikiene, 2015). This is due to the assumption that this behaviour would not be able to enhance their personal goals, thus they would be reluctant to perform this behaviour. On the other hand, individuals who have strong altruistic value would be more willing to engage in curtailment behaviour because they view this behaviour as something that can affect the welfare of others (Nordlund \& Garvill, 2003).

In this study, biospheric values are also found to be significant in predicting curtailment behaviour. As mentioned by (Steg et al., 2014), people with high biospheric values would be more motivated to conduct pro environmental behaviour, including curtailment behaviour because they think that protecting environment is a right thing to do. Personal norms were also found to significantly affect curtailment behaviour. This finding is in accordance with VBN theory. In VBN theory, personal norms are the closest predictor of behaviour (Garling et al., 2003). Personal norms are considered as the main ground of individuals' evaluation and predisposition towards environmental issue, and thus would determine how they would act in 
response of these environmental issue (Stern, 2000). Personal norms would make individuals feel obliged to conduct pro environmental behaviour as this is driven by their own internalized values (Jansson et al., 2010). As also asserted by (Tesla et al., 2016), individuals with higher level of personal norms would be more inclined to perform pro environmental behaviour, including curtailment behaviour.

This study gives contribution for government as policy maker and university as the educator. Based on the result, individuals' surrounding values and norms would highly determine their behaviour towards environment. In this regards, the formulation of policy and strategy to encourage the adoption of curtailment behaviour should incorporate values and norms. As postulated by Vermeir and Verbeke (2017), internalizing the right values and norms can contribute in preserving the environment, especially in the long run. And according to the result of this study, the relevant values and norms to influence curtailment behaviour of university students in Indonesia are altruistic values, biospheric values and personal norms as these factors are found to be statistically significant. For the university, strengthening values and norms about the importance of taking care and protecting the environment should be one of its major agendas. In this regards, the organization of study programs should incorporate the internalization of values and norms to the student.

The findings in this study also gives insight about the content for environmental campaign about the importance of curtailment behaviour. Based on the result, it is advisable to incorporate altruistic and biospheric values for the content of the campaign, as these two values are the ones found to be significant in influencing curtailment behaviour of students in Indonesia. Since altruistic values are focusing on welfare of other human and biospheric values are focusing on the welfare of the environment in general, the content of curtailment behaviour campaign should combine these two values. The content of the campaign should be able to highlight the impact of conducting curtailment behaviour to other people and the environment. For example, turning off the tap while brushing the teeth will be beneficial for other people because the saved water can be used by others (altruistic values) and also for the environment because it can preserve the water reservation (biospheric values).

In regards of personal norms, it is advisable to communicate the consequences of curtailment behaviour towards the welfare of other people and the environment. If the individuals are aware about the outcome of each action they taken, this would activate their moral obligations. One of the way to activate moral obligations is by implementing active norm management, which is an approach to alter behaviour through the utilization of appeals and campaign from well-known and respected public figures (Kinzig et al., 2003). As for the scale of the campaign, it is advisable to conduct a small-scale and personalized campaign. A small and personalized campaign is mentioned to be more effective because it makes the information becomes more relatable to the audience (Abrahamse et al., 2005).

\section{CONCLUSION}

This study tried to explore curtailment from values and norms perspective. Based on the result, values and norms can be utilized to encourage the adoption of curtailment behaviour in the context of university students in Indonesia. In this study, altruistic values play the biggest role in enhancing curtailment behaviour, as its beta value is higher than other proposed predictors. Besides altruistic values, biospheric values and personal norms are also significantly influencing curtailment behaviour of university students in Indonesia. Then, the adjusted $\mathrm{R}^{2}$ in this study is only $18.3 \%$ which implies that there is still a large amount of unexplained variance in curtailment behaviour. As asserted by Stern (2000), pro- 
environmental behaviour, including curtailment behaviour, can be explored from 4 perspectives, namely contextual factor, habit, personal capability and attitudinal factors. This study only explores curtailment behaviour from one perspective, which is attitudinal factors. Therefore, it is advisable for future studies to explore curtailment behaviour from other perspectives, like contextual, habit or capabilities.

\section{REFERENCES}

Abrahamse, W., Steg, L., Vlek, C., \& Rothengatter, T. (2005). A review of intervention studies aimed at household energy conservation. Journal of Environmental Psychology, 25(3), 273-291.

Andersson, M., \& von Borgstede, C. (2010). Differentiation of determinants of low-cost and high-cost recycling. Journal of Environmental Psychology, 30(4), 402-408.

Ando, K., Ohnuma, S., \& Chang, E. C. (2007). Comparing normative influences as determinants of environmentally conscious behaviours between the USA and Japan. Asian journal of social psychology, 10(3), 171-178.

Bouman, T., Steg, L., \& Kiers, H. A. (2018). Measuring values in environmental research: a test of an environmental portrait value questionnaire. Frontiers in psychology, 9, 564.

Cortese, A. D. (2003). The critical role of higher education in creating a sustainable future. Planning for higher education, 31(3), 15-22.

De Groot, J. I., \& Steg, L. (2008). Value orientations to explain beliefs related to environmental significant behaviour: How to measure egoistic, altruistic, and biospheric value orientations. Environment and Behaviour, 40(3), 330-354.

De Groot, R., Brander, L., Van Der Ploeg, S., Costanza, R., Bernard, F., Braat, L., \& Hussain, S. (2012). Global estimates of the value of ecosystems and their services in monetary units. Ecosystem Services, 1(1), 50-61

Dermody, J., Koenig-Lewis, N., Zhao, A. L., \& Hanmer-Lloyd, S. (2018). Appraising the influence of pro-environmental self-identity on sustainable consumption buying and curtailment in emerging markets: Evidence from China and Poland. Journal of Business Research, 86, 333-343.

Dietz, T., Fitzgerald, A., \& Shwom, R. (2005). Environmental values. Annu. Rev. Environ. Resour., 30, 335-372.

Elster, J. (1989). Social norms and economic theory. Journal of economic perspectives, 3(4), 99-117.

Ferial (2016). Perubahan Perilaku Kunci Hemat Energi. Retrieved June 10, 2019, from http://ebtke.esdm.go.id/post/2016/08/15/1315/perubahan.perilaku.kunci.hemat.energi

Gardner, B., \& Abraham, C. (2007). What drives car use? A grounded theory analysis of commuters' reasons for driving. Transportation Research Part F: Traffic Psychology and Behaviour, 10(3), 187-200.

Gärling, T., Fujii, S., Gärling, A., \& Jakobsson, C. (2003). Moderating effects of social value orientation on determinants of proenvironmental behaviour intention. Journal of environmental psychology, 23(1), 1-9.

Golob, U., Kos Koklic, M., Podnar, K., \& Zabkar, V. (2018). The role of environmentally conscious purchase behaviour and green scepticism in organic food consumption. British Food Journal, 120(10), 2411-2424.

Harland, P., Stats, H., \& Wilke, H. A. (2007). Situational and personality factors as direct or personal norm mediated predictors of pro-environmental behaviour: Questions derived from norm-activation theory. Basic and applied social psychology, 29(4), 323-334.

Ibtissem, M.H. (2010). Application of value beliefs norms theory to the energy conservation behaviour. Journal of Sustainable Development, 3(2), 129. 
Jansson, J., Marell, A., \& Nordlund, A. (2010). Green consumer behaviour: determinants of curtailment and eco-innovation adoption. Journal of Consumer Marketing, 27(4), 358-370.

Jansson, J., \& Dorrepaal, E. (2015). Personal norms for dealing with climate change: results from a survey using moral foundations theory. Sustainable Development, 23(6), 381-395.

Kim, H., Lee, E. J., \& Hur, W. M. (2012). The mediating role of norms in the relationship between green identity and purchase intention of eco-friendly products. Human Ecology Review, 125-135.

Kinzig, A.P., Ehrlich, P.R., Alston, L., \& Ostrom, E. (2013). Social norms and global environmental challenges: the complex interaction of behaviours, values, and policy. BioScience, 63(3), 164-175.

Klain, S. C., Olmsted, P., Chan, K. M., \& Satterfield, T. (2017). Relational values resonate broadly and differently than intrinsic or instrumental values, or the New Ecological Paradigm. PLoS One, 12(8), e0183962.

Knapp, T, \& Mueller, R. (2010), "Reliability and Validity of Instruments”. In: The Reviewer's Guide to Quantitative Methods in the Social Sciences, G. Hancock, \& R. Mueller, New York, Routledge, pp. 337-355.

Liobikienè, G., \& Juknys, R. (2016). The role of values, environmental risk perception, awareness of consequences, and willingness to assume responsibility for environmentally-friendly behaviour: the Lithuanian case. Journal of Cleaner Production, 112, 3413-3422.

Luchs, M. G., Naylor, R. W., Rose, R. L., Catlin, J. R., Gau, R., Kapitan, S., \& Simpson, B. (2011). Toward a sustainable marketplace: Expanding options and benefits for consumers.

Malhotra, N.K. (2010), Marketing Research: An Applied Orientation, 6th Edition, New Jersey, Prentice Hall.

Manstead, A.S. (2000). The role of moral norm in the attitude-behaviour relation. In D.J. Terry \& M.A. Hogg (Eds.), Applied social research. Attitudes, behaviour, and social context: The role of norms and group membership (pp. 11-30). Mahwah, NJ, US: Lawrence Erlbaum Associates Publishers.

Marroli (2017). Hemat Energi "Potong 10\%" Dorong Kesadaran Pemanfaatan Energi Bertanggung Jawab. Retrieved June 10, 2019, from https://kominfo.go.id/index.php/ content/detail/9680/hemat-energi-potong-10-dorong-kesadaran-pemanfaatan-energibertanggung-jawab/0/artikel_gpr

Medina, V., Deronda, A., Ross, N., Curtin, D., \& Jia, F. (2019). Revisiting Environmental Belief and Behaviour Among Ethnic Groups in the US. Frontiers in Psychology, 10, 629.

Müller-Christ, G., Sterling, S., van Dam-Mieras, R., Adomßent, M., Fischer, D., \& Rieckmann, M. (2014). The role of campus, curriculum, and community in higher education for sustainable development a conference report. Journal of Cleaner Production, 62, 134-137.

Nordlund, A.M., \& Garvill, J. (2003). Effects of values, problem awareness, and personal norm on willingness to reduce personal car use. Journal of Environmental Psychology, 23(4), 339-347.

Onel, N., \& Mukherjee, A. (2017). Why do consumers recycle? A holistic perspective encompassing moral considerations, affective responses, and self-interest motives. Psychology \& Marketing, 34(10), 956-971. 
Robinson, R., \& Smith, C. (2002). Psychosocial and demographic variables associated with consumer intention to purchase sustainably produced foods as defined by the Midwest Food Alliance. Journal of Nutrition Education and Behaviour, 34(6), 316-325.

Schultz, P. W., \& Zelezny, L. (1999). Values as predictors of environmental attitudes: Evidence for consistency across 14 countries. Journal of environmental psychology, 19(3), 255-265.

Schultz, P. W., Gouveia, V. V., Cameron, L. D., Tankha, G., Schmuck, P., \& Franěk, M. (2005). Values and their relationship to environmental concern and conservation behaviour. Journal of cross-cultural psychology, 36(4), 457-475.

Schwartz, S.H. (1992). Universals in the content and structure of values: Theoretical advances and empirical tests in 20 countries. Advances in Experimental Social Psychology, 25, $1-65$.

Sheldon, K. M. (2005). Positive value change during college: Normative trends and individual differences. Journal of Research in Personality, 39(2), 209-223.

Steg, L., Dreijerink, L., \& Abrahamse, W. (2005). Factors influencing the acceptability of energy policies: A test of VBN theory. Journal of environmental psychology, 25(4), 415-425.

Steg, L., Bolderdijk, J. W., Keizer, K., \& Perlaviciute, G. (2014). An integrated framework for encouraging pro-environmental behaviour: The role of values, situational factors and goals. Journal of Environmental psychology, 38, 104-115.

Stern, P. C., Dietz, T., \& Kalof, L. (1993). Value orientations, gender, and environmental concern. Environment and behaviour, 25(5), 322-348.

Stern, P. C., Dietz, T., \& Guagnano, G. A. (1998). A brief inventory of values. Educational and psychological measurement, 58(6), 984-1001.

Stern, P. C. (2000). New environmental theories: toward a coherent theory of environmentally significant behaviour. Journal of social issues, 56(3), 407-424.

Stevens, J. (2009), Applied Multivariate Statistics for the Social Sciences, 5th Edition, New York, Routledge.

Tanner, C., \& Wölfing Kast, S. (2003). Promoting sustainable consumption: Determinants of green purchases by Swiss consumers. Psychology \& Marketing, 20(10), 883-902.

Thøgersen, J. (2006). Norms for environmentally responsible behaviour: An extended taxonomy. Journal of Environmental Psychology, 26(4), 247-261.

Urien, B., \& Kilbourne, W. (2011). Generativity and self-enhancement values in eco-friendly behavioural intentions and environmentally responsible consumption behaviour. Psychology \& marketing, 28(1), 69-90.

Vermeir, I., \& Verbeke, W. (2008). Sustainable food consumption among young adults in Belgium: Theory of planned behaviour and the role of confidence and values. Ecological Economics, 64(3), 542-553

Wang, Y. (2017). Promoting sustainable consumption behaviours: The impacts of environmental attitudes and governance in a cross-national context. Environment and Behaviour, 49(10), 1128-1155.

Whitley, C. T., Takahashi, B., Zwickle, A., Besley, J. C., \& Lertpratchya, A. P. (2018). Sustainability behaviours among college students: An application of the VBN theory. Environmental Education Research, 24(2), 245-262.

Yeboah, F. K., \& Kaplowitz, M. D. (2016). Explaining energy conservation and environmental citizenship behaviours Using the Value-Belief-Norm Framework. Human Ecology Review, 22(2), 137-160. 